\title{
Література:
}

1. STЕМ-освіта як перспективна форма інноваційної освіти в Україні Матеріали обласної науково-практичної інтернет-конференції. / Авторупорядник Ю. М. Зоря. - Черкаси: ЧОІПОПП, 2018. - 117 с.

2. Іванюк Т. STEM як освітній ресурс XXI століття. STEM-освіта та шляхи iї впровадження в навчально-виховний процес. Тернопіль, 2017.- C. 14-18.

3. Кириленко С., Кіян О. Проблема підготовки вчителя у системі STEM-освіти: розвиток та формування його професійної компетентності. STEM-освіта: стан впровадження та перспективи розвитку: матеріали III Міжнародної науково-практичної конференції, 9-10 листопада 2017 р., м. Київ. Київ: ДНУ «Інститут модернізації змісту освіти», 2017. - 160 с.

4. Концепція «Нова українська школа». Інформаційний збірник $\mathrm{MOH}$ України. // [Електронний ресурс]. - Режим доступу: http://mon.gov. ua.

5. Ночевчук М. Впровадження елементів STEM-освіти у навчання матемапики та фізики // [Електронний ресурс]. - Режим доступу: https://vseosvita.ua/library/statta-na-temu-vprovadzenna-elementiv-stemosviti-u-navcanna-matematiki-ta-fiziki-84380.html.

DOI https://doi.org/10.30525/978-9934-26-039-1-93

\section{INNOVATIVE METHODS OF TEACHING FOREIGN LANGUAGES MODERN LOOK}

\author{
Koliesnikov R. O. \\ Teacher of the English Language \\ Municipal Establishment «Kharkiv special school No. 7» of the Kharkiv \\ Regional Council, \\ Postgraduate Student \\ Municipal Establishment «Kharkiv Humanitarian-Pedagogical Academy» \\ of the Kharkiv Regional Council \\ Kharkiv, Ukraine
}

The modern educational context is characterized by processes that are associated with a change in ideas about the essence and goals of education, which is rapidly developing missay innovative processes, unification of national educational standards, updating social requirements for the system of training specialists and their readiness for development and training. 
The vocational school becomes an institution for the socialization of the individual and the reproduction of the cadre potential of society. Such transformations give rise to the need to search for other approaches to the organization of the educational process that can provide an opportunity for self-development and self-realization, change the view on the place and activities of the teacher in modern society.

The pedagogical profession requires constant creative readiness, the search for non-professional, and at the same time, optimal solutions to professional situations [1].

In turn, this justifies an in-depth study of the functions of teacher education, strategies for its development and the choice of a role in economic and social progress as objective regularity.

The problem of the continuity of teacher training in its theoretical, practical and organizational aspects has been actualized in recent years and needs a detailed study, since it plays an important role in reforming the Russian system of training teachers and adapting to the requirements of the international educational space.

In the conditions of an actively developing two-level system of pedagogical education in Ukraine, there is objectively a need to study the qualitative changes in the organization of a foreign pedagogical school that have occurred in recent decades: the creation of new types of educational institutions; development of variable educational plans and programs; restructuring the content of education; implementation of modern teaching technologies, etc [2].

The study of the rich world experience in the field of teaching staff training can serve to a certain extent as a guide in predicting the development of the domestic education system, taking into account the characteristics of our society and those specific tasks that face the pedagogical community of our country in modern conditions.

The Canadian system of continuous pedagogical education is of particular interest for domestic pedagogical science and practice, since the process of training and retraining of teachers in this multinational country accumulates the experience of different nations regarding the organization of the educational process using modern innovative technologies.

The introduction of multimedia technologies creates conditions for interactive communication, which today is the most important component of the educational process. Using multimedia technologies, the teacher can present information in a completely new and effective form, make it more complete, interesting and close to the subject of communication being studied. 
As well as multimedia technologies allow you to develop bright and more interesting speaking exercises [1].

For students, learning a foreign language using multimedia technologies also has certain advantages. Given the novelty of these technologies, it is interesting for students to deal with sources of new types of information. And it is also important that the assimilation of new information using multimedia technologies takes place in the form of games. The use of multimedia technologies allows students to independently prepare mini-projects on the subject of communication and present them.

When mastering a foreign language, students have a number of problems, one of which is low motivation to learn the language. In such cases, it is interactive technologies that are valuable for application, because they create such conditions when the student feels his success and intellectual ability.

Interactive learning involves some methods of cooperation in the learning process. Successful completion of the task set for the whole group depends entirely on the successful completion of this task personally by each student, the responsibility of each for the implementation of their task [3].

Effective collaboration and communication are basic components of such training, which aims to solve problems together, acquire monologue skills, responsibility, critical thinking and achieve meaningful results. That is why the learning process should be activated by the use of interactive technologies depending on the goal and objectives set before it. Ways to integrate interactive methods into the learning process are virtually limitless.

It was found that at each stage of the lesson it is advisable to use different methods, range of ideas, simulation games, etc. Also, a very important role here will be played by the type of lesson and its place in the cycle of lessons on this topic. The interactive form of work has significant advantages over the frontal and individual forms: in groups, students are involved in collective creative activity, meaningful communication and interaction, the division of labor between group members; mutual learning and mutual control is carried out [1].

Special attention is paid to interactive learning of writing and reading. Interactive teaching of written speech in higher education should form and develop the skills of discussion, analysis and peer review.

The modern model of the reading process is focused on the interactive connection between the reader and the text being studied. The teacher should submit the text, organize tasks that will help students understand it (or allow the teacher to see how much they did not understand it), and then just follow the work on the text and time, adjust them. The text must be chosen correctly, 
the tasks must correspond to the type of text, type of reading, the level of language training of students.

Thus, we can conclude that the effectiveness of innovative approaches to teaching foreign languages in modern school will depend on the desire and ability of teachers to use the positive experience of domestic and foreign scholars and practitioners on a creative approach to learning, understanding the need to abandon authoritarian and scholastic methods [1].

Innovative methods of teaching foreign languages, which are based on a creative approach, help to fully unleash the potential of students and contribute to the development and self-improvement of the educational and communicative process.

Selection, theoretical understanding, classification of pedagogical innovations deals with a new branch of pedagogical knowledge - pedagogical innovation (Latin innovation - renewal, change). Innovations in pedagogy are associated with general processes in society, global problems, integration (Latin integration - restoration, unification of individual elements) of knowledge and forms of social life. Now a new pedagogy is being created, the characteristic feature of which is innovation - the ability to renew, openness to the new.

Most innovative teaching methods have difficulties in preparing lessons for them and, according to teachers, increase the time required to prepare for lessons and reduce the number of tasks that children perform over time.

However, teachers who aim to productively teach their students must understand that it is impossible to overestimate modern methods.

In order to develop the creative abilities of students, their gradual and systematic involvement in independent cognitive activity, ensuring cooperation between students and teachers, they did not use only the traditional lesson. Therefore, every teacher should think about changing the form of the lesson in some cases. This is especially true of English lessons, where most of the lesson is spent on developing students' skills and skills, application of acquired theoretical knowledge.

Conclusion. Thus, the combination of traditional methods and approaches with some, in our case - the latest trends, significantly increase and optimize the activity and productivity of students in the process of learning a foreign language. Therefore, it is important to further search for new trends and applications in the process of learning a foreign language.

\section{References:}

1. Barakhsanova E.A., Varlamova V.A. Teaching and methodological support of the implementation of the principle of regionalization of education 
in the process of teaching the block of information disciplines // Modern problems of science and education. - 2015. - № 5 URL: http://www.scienceeducation.ru/ru/article/view?id=22282 (date accessed: 02/07/2021).

2. Pometun O. Interactive learning technologies: theory, practice, experience / O. Pometun, L. Pirozhenko. - Kyiv, 2002. - 98 p.

3. Traditions and innovations in methods of teaching foreign languages: [textbook. way. for students. and teaches.] / [ed. M.K. Kolkovoy]. 2007. $-267 \mathrm{c}$.

DOI https://doi.org/10.30525/978-9934-26-039-1-94

\title{
ДИСТАНЦІЙНЕ ВИВЧЕННЯ ІНОЗЕМНОЇ МОВИ ДЛЯ РОЗВИТКУ КРИТИЧНОГО МИСЛЕННЯ СТУДЕНТІВ
}

\author{
Колосова Г. А. \\ кандидат філологічних наук, \\ доиент кафедри англійської мови гуманітарного спрямування № 3 \\ Національний технічний університет Украйни \\ «Київський політехнічний інститут імені Ігоря Сікорського» \\ м. Київ, Украӥна
}

Проблема «мислення» в різноманітних психолого-педагогічних аспектах є актуальним питанням для вітчизняних і зарубіжних науковців. Важливість та недостатня розробленість цього питання надихнули дослідників до наукового обгрунтування та експериментального впровадження інноваційних методів розвитку критичного мислення студентів вищих навчальних закладів (далі ВН3) на заняттях 3 іноземної мови. Коли людина мислить критично, вона оцінює результати своїх розумових процесів - наскільки правильно ухвалене нею рішення або наскільки вдало вона впорались із поставленим завданням [1, с. 34]. Автономія отримання та практичне застосування знань за допомогою дистанційного навчання стали вагомими проблемами для сучасного студента. Адже, студентська молодь проявляє бажання розпоряджатися можливістю розвивати критичне мислення протягом життя в умовах інформатизованого суспільства.

Питаннями розвитку критичного мислення у студентів займались такі науковці як Andrade D. F., Collin K., Dewey J., Drasgow F., Facione P. A., Harré R., Huitt W., Hulin C. L., Lave J., Wenger E., Paloniemi S., Pasquali L., 